\title{
Sosialisasi Pencegahan Cedera Pada Calon Wasit Sepakbola Lisensi C2 ASPROV PSSI Bengkulu
}

Dian Pujianto ${ }^{1}$, Syafrial ${ }^{2}$, Bayu Insanistyo ${ }^{3}$

${ }^{123}$ Program Studi Pendidikan Jasmani, Universitas Bengkulu Email : dianpujianto@unib.ac.id

\section{Article History: \\ Received: Oktober \\ Revised: Oktober \\ Accepted: November \\ Available online:Desember}

Kata Kunci: Cedera, Sosialisasi, Sepakbola, Wasit

\begin{abstract}
Abstrak:
Pengabdian ini bertujuan untuk memberikan bekal pengetahuan dasar cedera dan pencegahan cedera olahraga pada calon wasit sepakbola Lisensi C PSSI Asprov Bengkulu. Sasaran pengabdian adalah calon wasit sepakbola yang berada dibawah naungan Asprov Bengkulu atau yang mewakili Askab/Askot PSSI di Bengkulu, sebanyak 20 orang. Peserta berasal darai 9 kabupaten dan 1 kota yang ada di Provinsi Bengkulu. Metode pengabdian dengan ceramah dan diskusi. Hasil pengabdian menunjukkan adanya peningkatan pengetahuan dan kemampuan tentang cedera dan penanganan cedera serta pencegahan cedera sebagai bekal pengetahuan dalam memimpin pertandingan. Peserta mampu memahami bahaya cedera yang berkepanjangan, dan pengetahuan ini merupakan informasi baru bagi peserta pelatihan.
\end{abstract}




\section{Pendahuluan}

Cedera dalam olahraga merupakan masalah yang sering timbul. Terutama pada cabang olahraga sepakbola, dimana kontak fisik sering terjadi dan berakibat pada timbulnya cedera pada pemain sepakbola. Penanganan pertama pada cedera akan memberikan dampak positif terhadap kecepatan pemulihan atlet dari cedera. Untuk itu orang yang berada dalam lapangan harus memiliki pengetahuan dasar tentang cedera yang terjadi pada atlet saat bertanding. Berkaitan dengan permasalahan ini salah satu sosok yang memiliki peran penting terhadap penanganan cedera secara cepat adalah wasit yang ada di tengah lapangan.

Berkaitan dengan permasalahan ini maka ASPROV PSSI Bengkulu bekerjasama dengan Program Studi Pendidikan Jasmani FKIP Universitas Bengkulu memberikan pembekalan kepada calon wasit sepakbola lisensi C2 berupa penanganan dan pencegahan cedera pada olahraga. Pembekalan pengetahuan ini akan memberikan pengetahuan kepada calon wasit tentang kondisi cedera yang terjadi pada atlet, dan wasit akan mampu memberikan intruksi secara tepat kepada tim medis yang ada di lapangan, sehingga atlet dapat tertolong dari cedera yang lebih parah.

Prinsip dalam sepakbola sederhana sekali yaitu membuat gol dan mencegah jangan sampai lawan berbuat sama terhadap gawang sendiri (Elgert, 2012). Pendapat lain juga dikemukakan oleh (Villela, 2013), bahwa, "Semua pemain sepakbola harus menguasai teknik dasar dan keterampilan bermain sepakbola, karena orang akan menilai sampai mana teknik dan keterampilan para pemain dalam hal menendang bola, memberikan bola, menyondol bola, menembakkan bola ke gawang lawan untuk mencetak gol”.

Berdasarkan pendapat di atas dapat disimpulkan bahwa sepakbola merupakan permainan beregu, dan terjadi kontak fisik antara sesama pemain. Sehingga dibutuhkan peran pengadil di tengah lapangan atau wasit untuk menghidari terjadinya hal-hal yang tidak diinginkan. Semua jenis cedera saat berolahraga, disebabkan karena pembebanan yang berlebihan terhadap jaringan tubuh. Anak-anak yang berolahraga, rawan terhadap cedera, terutama pada pusat-pusat pertumbuhan, seperti lutut, pergelangan tangan, tulang belakang, dan lain-lain.

Aktifitas fisik berlebihan mengakibatkan robekan jaringan minimal (mikrotrauma) yang tidak terlihat dari luar. Apabila mikrotrauma ini berlangsung berulangkali, maka menimbulkan cedera, pertolongan pertama 
pada cedera secara tepat dapat meminimalisir cedera yang lebih arah sebagai akibat cedera kecil seperti, seperti keseleo, memar otot, patah tulang dan lain-lain. Latihan fisik yang berat pada anak, tanpa waktu pemulihan yang memadai, karena jadwal kompetisi yang padat akan mengakibatkan resiko cedera.

Cedera adalah suatu kerusakan pada struktur atau fungsi tubuh yang dikarenakan suatu paksaan atau tekanan fisik maupun kimia (And \& Walker, 2013). Sport Injuries (cedera olahraga) ialah segala macam cedera yang timbul, baik pada waktu latihan maupun pada waktu berolahraga (pertandingan) ataupun sesudahnya. Bagian yang biasanya mengalami cedera ialah tulang, otot, tendon, serta ligamentum. Dengan demikian pengetahuan pengetahuan tentang cedera olahraga berguna untuk mempelajari cara terjadinya cedera olahraga, pencegahan serta penanganan cedera olahraga. Di dalam ilmu kesehatan diutamakan tindakan pencegahan (preventif) daripada tindakan pengobatan (kuratif) (Hellewell et al., 2020), karena :

1. Mencegah memerlukan biaya yang lebih ringan daripada mengobati.

2. Jika tindakan pengobatan tidak sempurna akan dapat menimbulkan cacat

3. Ketika sakit dapat mengurangi daya produktifitas.

\section{Metode}

Metode kegiatan dilakukan dengan ceramah (Pujianto \& Insanistyo, 2013). Selain ceramah metode kedua yang digunakan adalah diskusi kelompok, dengan pendekatan kooperatif (Pujianto, Insanistyo, et al., 2020).Kegiatan pengabdian dimulai dengan sosialisasi terhadap masyarakat oleh PSSI. PSSI dalam hal ini Asosiasi Provinsi (ASPROV) PSSI Bengkulu mensosialisasikan kegiatan pelatihan perwasitan sepakbola lisensi C di Provinsi Bengkulu. Sebagai tindak lanjut kegiatan ini maka setiap Asosiasi Kabupaten (ASKAB) PSSI mengirimkan perwakilannya dalam pelatihan. Berdasarkan rekomendasi dari setiap ASKAB PSSI mengirimkan 2 delegasi, kecuali Asosiasi Kota (ASKOT) Bengkulu sebagai tuan rumah mengirimkan 7 delegasi, sehingga subyek pengabdian berjumlah 25 orang. Tahap selanjutnya adalah perencanaan kegiatan, pemateri berkoordinasi dengan panitia menyusun jadwal kegiatan, tahap berikutnyanya adalah pelaksanakan kegiatan, setelah kegiatan dilaksanakan tahap terakhir adalah evaluasi kegiatan pengabdian. Kegiatan pengabdian dilakukan melalui beberapa macam metode, yaitu; ceramah, diskusi, dan praktek. Ketiga pendekatan ini 
digunakan secara bergantian ketika pemateri memberikan sosialisasi di ASPROV PSSI Bengkulu.

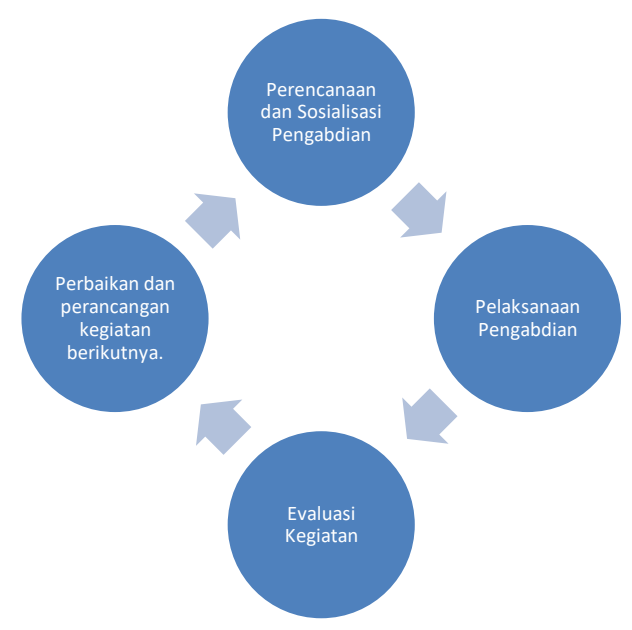

Gambar 1. Alur Kegiatan Pengabdian

\section{Hasil}

Berdasarkan hasil tes awal pengetahuan cedera olahraga dan pencegahan terhadap cedera olahraga peserta kursus wasit sepakbola Asprov PSSI Bengkulu, ternyata hasilnya masih memnggambarkan kondisi pengetahuan calon wasit masih rendah terhadap cedera dan pencegahan cedera pada olahraga. Berdasarkan tes awal yang telah dilaksanakan ternyata hanya 1 peserta yang memiliki nilai baik dari 20 peserta, dan berikut ini hasil pre tes peserta Kursus wasit lisensi C.

Tabel.1. Hasil Tes Awal

\begin{tabular}{ccc}
\hline No & Rentang Nilai & Frekuensi \\
\hline 1 & $9-10$ & 0 \\
\hline 2 & $7-8$ & 1 \\
\hline 3 & $5-6$ & 10 \\
\hline 4 & $3-4$ & 8 \\
\hline 5 & $1-2$ & 1 \\
\hline & Jumlah & 20 \\
\hline
\end{tabular}


Berdasarkan data tabel 1 peserta yang memperoleh nilai 1 sampai 2 ada 1 peserta, peserta yang memperoleh nilai 3 sampai 4 ada 8 peserta, peserta yang memperoleh nilai 5 sampai 6 ada 10 peserta dan peserta yang memperoleh nilai 7 sampai 8 ada 1 peserta. Berdasarkan perolehan nilai ini maka jelas bahwa pengetahuan peserta tentang cedera dan pencegahan cedera olahraga masih rendah. Peserta lebih menguasai penguasaan lapangan saat pertandingan. Peserta lebih focus pada bagaimana memutuskan dengan cepat dan tepat terhadap pelanggaran dalam permainan sepakbola. Mereka belum mampu melihat bagaimana kondisi cedera yang harus segera ditangani dan cedera yang dapat dirawat kemudian, sehingga tidak membahayakan pemain sepakbola. Berikut ini gambar grafik batang hasil tes awal;

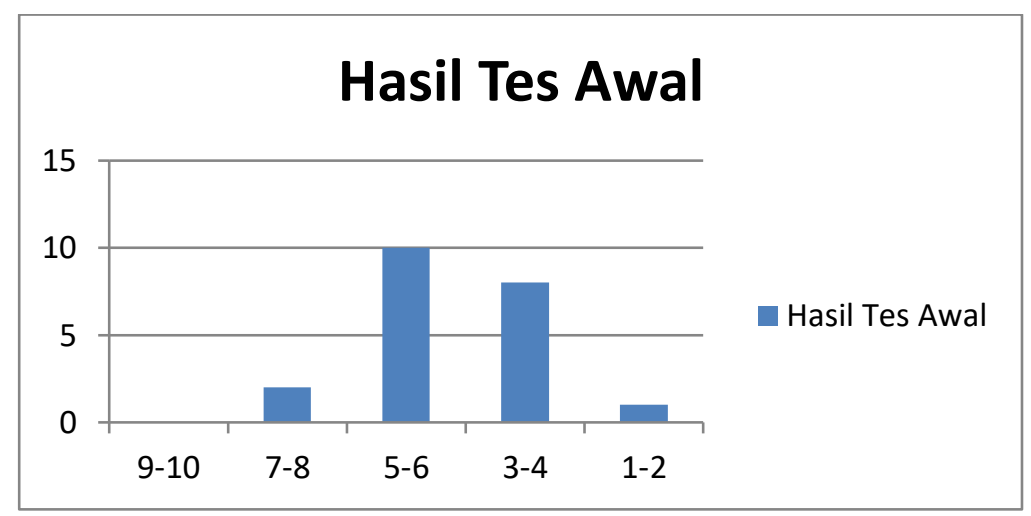

Gambar 2. Hasil Tes Awal

Tahap selanjutnya adalah melaksanakan kegiatan yaitu pelatihan pengenalan cedera dan pencegahan cedera pada olahraga. Pelatihan menggunakan metode ceramah dan diskusi kelompok. Setelah selesai pelatihan maka dilakukan post test, berikut ini hasil post test dari peserta;

Tabel.2. Hasil Tes Akhir

\begin{tabular}{ccc}
\hline No & Rentang Nilai & Frekuensi \\
\hline 1 & $9-10$ & 9 \\
\hline 2 & $7-8$ & 10 \\
\hline 3 & $5-6$ & 2 \\
\hline 4 & $3-4$ & 0 \\
\hline 5 & $1-2$ & 0 \\
\hline & Jumlah & 20 \\
\hline
\end{tabular}


Berdasarkan tabel 2 diperoleh data peserta, ada 2 peserta memperoleh nilai 5 - 6. Ada 10 peserta memperoleh nilai $7-8$, dan ada 9 peserta memperoleh nilai 9 - 10. Berdasarkan data ini maka dapat ditarik simpulan bahwa ada peningkatan nilai kognitif peserta setelah mendapatkan materi cedera olahraga dan penanganan cedera olahraga. Berikut ini gambar grafik batang tes akhir,

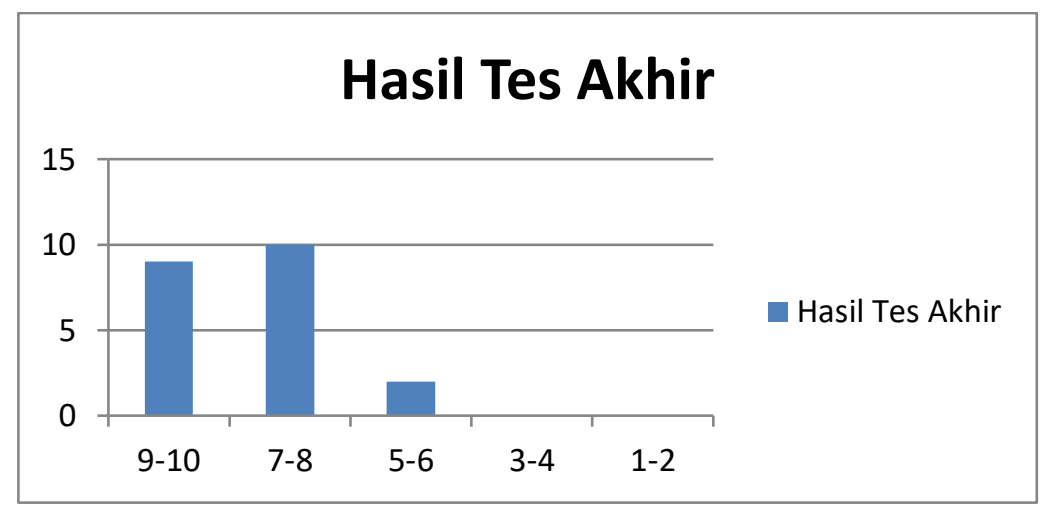

Gambar 3. Tes Akhir

Berikut ini adalah dokumetasi kegiatan pengabdian masyarakat yang telah dilaksanakan,

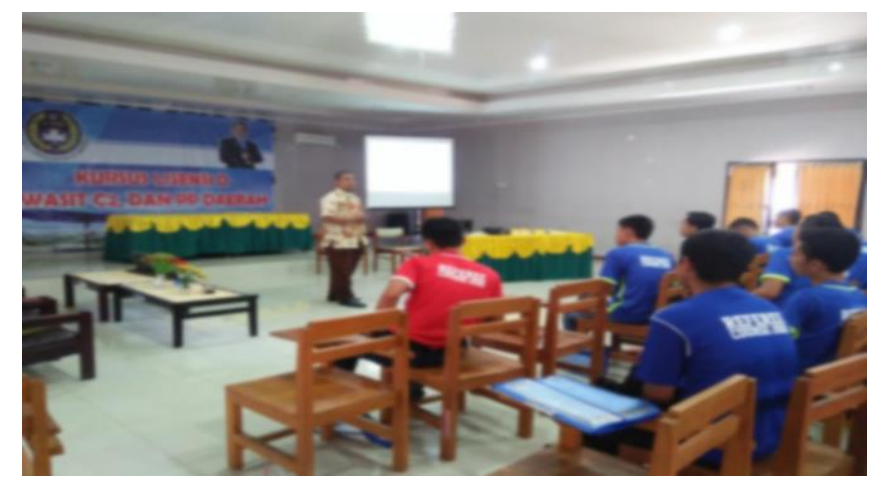

Gambar 4. Pelaksanaan Pengabdian pada Masyarakat

\section{Diskusi}

Kegiatan ini telah dilaksanakan pada bulan Juni 2018. Kegiatan ini dilakukan dengan cara memberikan bentuk pelatihan pencegahan cedera dan penanganan cedera pada calon wasit sepakbola lisensi C di Provinsi Bengkulu. Pengetahuan wasit sepakbola terhadap cedera pemain saat bermain sepakbola menjadi kunci penting dalam pertandingan sepakbola. 
Permainan sepakbola banyak menggunakan tungkai dan kaki, passing dilakukan dengan kaki (Pujianto, Sutisyana, et al., 2020). Sehingga kaki selalu bekerja terus menerus yang berakibat rawan kelelahan dan menjadi cidera. Maka pengetahuan tentang timbilnya cedera pada pemain sepakbola penting. Semakin baik pengetahuan cedera yang dimiliki oleh wasit maka cedera atlet sepakbola akan semakin cepat disembuhkan atau tertangani oleh tim medis, sehingga pemain akan terhindar dari cacat permanen bahkan kematian (Maak et al., 2020). Permainan sepakbola merupakan permainan kontak fisik langsung yang menyebabkan rawan terjadinya cedera (Jelveus \& Oddson, 2011), sehingga seorang wasit harus memiliki bekal pengetahuan cedera olahraga Wasit juga memiliki peran dalam memberikan penguatan ketika pemain mengalami cedera (Arvinen-Barrow \& Walker, 2013). Dalam hal ini wasit memutuskan kondisi sang pemain untuk dapat segera diberikan pertolongan. Melalui kegiatan ini peserta juga telah memahami bagaimana cedera yang berbahaya bagi pemain maupun cedera yang tidak berbahaya bagi pemain. Pengetahuan mengenai cedera dapat menyelamatkan pemain sepakbola dari cedera yang parah atau bahkan yang menyebabkan kematian. Selain kesiapan atlet dalam berolahraga baik kesiapan secara teknik, taktik dan fisik (Elphinston, 2008). Peran wasit juga sangat krusial ketika terjadi benturan antara pemian yang menyebabkan munculnya cedera, pengetahuan wasit menjadikan atlet segera tertolong atau terlambat dalam penanganan cedera, yang dapat berakibat karier atlet menjadi terhenti.

\section{Kesimpulan}

Pengetahuan cedera olahraga bagi wasit sepakbola penting bagi lancaranya sebuah pertandingan sepakbola. Pengetahuan cedera dan penanganan cedera pada wasit juga dapat menyelamatkan pemain dari cedera parah bahkan menyelamatkan pemain dari kematian. Saran untuk kegiatan ini adalah lingkup pengabdian harus diperluas sehingga masyarakat olahraga secara umum dapat terjangkau.

\section{Pengakuan}

Ucapan terima kasih kepada Fakultas Keguruan dan Ilmu Pendidikan Universitas Bengkulu dan ASPROV PSSI Bengkulu yang telah menfasilitasi dan membiayai pengabdian ini.

\section{Daftar Referensi}

And, M. A.-B., \& Walker, N. (2013). THE PSYCHOLOGY OF SPORT INJURY AND REHABILITATION. Routledge. 
Arvinen-Barrow, M., \& Walker, N. (2013). The psychology of sport injury and rehabilitation. In The Psychology of Sport Injury and Rehabilitation. https://doi.org/10.4324/9780203552407

Elgert, P. S. \& N. (2012). Attacking Soccer Mastering the Modern GameNo Title. Meyer \& Meyer Sport.

Elphinston, J. (2008). Stability, Sport and Performance Movement Great Technique Without Injury (I).

Hellewell, S. C., Nguyen, V. P. B., Jayasena, R. N., Welton, T., \& Grieve, S. M. (2020). Characteristic patterns of white matter tract injury in sportrelated concussion: An image based meta-analysis. NeuroImage: Clinical, 26(February), https://doi.org/10.1016/j.nicl.2020.102253

Jelveus, A., \& Oddson, K. (2011). Integrated Sports Massage Therapy. In C. Wilson (Ed.), Elsevier. Churchill Livingstones Elsevier. https://doi.org/10.1017/CBO9781107415324.004

Maak, T. G., Mack, C. D., Cole, B. J., Herzog, M. M., Difiori, J., \& Meisel, P. (2020). Sports Performance and Injury Research: Methodologic Limitations and Recommendations for Future Improvements. Arthroscopy: The Journal of Arthroscopic \& Related Surgery : Official Publication of the Arthroscopy Association of North America and the International Arthroscopy Association, 36(11), 2938-2941. https://doi.org/10.1016/j.arthro.2020.08.038

Pujianto, D., \& Insanistyo, B. (2013). Dasar Dasar Penelitian Pendidikan Jasmani (First). FKIP Universitas Bengkulu.

Pujianto, D., Insanistyo, B., Syafrial, Sutisyana, A., \& Arwin. (2020). Using Cooperative Learning to Teach Team Game Tournament Structure in Learning Physical Education and Sports. 464(Psshers 2019), 309-314. https://doi.org/10.2991/assehr.k.200824.073

Pujianto, D., Sutisyana, A., \& Arwin, A. (2020). Pengembangan Model Latihan Sasaran Berbasis Permainan Untuk Meningkatkan Kemampuan Passing Sepakbola. Multilateral Jurnal Pendidikan Jasmani Dan Olahraga, 19(1), 67-73. https://doi.org/10.20527/multilateral.v19i1.8333

Villela, lucia maria aversa. (2013). Dutch Soccer Secrets. In Journal of Chemical Information and Modeling (Vol. 53, Issue 9). 